Љиљана Мацура

Народна библиотека Србије
УДК 026:355.354

доИ https://doi.org/10.18485/

melissa.2016.15.1.ch13

\title{
БИБЛИОТЕКЕ ВАЗДУХОПЛОВНИХ УСТАНОВА У СРБИЈИ
}

\begin{abstract}
Сажетак
Неопходност коришћења савремених информационо-комуникационих технологија и природа ваздухопловне информације чине предуслове да се ваздухопловним библиотекама међу првима додели атрибут виртуелног. Библиотеке ваздухопловних установа сврставају се у домен специјалног и високошколског библиотекарства, па се и значај ове теме огледа управо у дефинисању домаћег специјалног и високошколског библиотекарства у области ваздухопловства. Истраживање је пошло од претпоставке да се у ваздухопловним установама поред њихове основне, одвија и библиотечко-информациона делатност, а извршено је са циљем да се утврди степен развоја у овом домену библиотечко-информационе делатности и ваздухопловства, као и проналажење начина за унапређење. Предмет анализе били су организационо окружење, библиотечко-информациона грађа и извори и место ваздухопловног библиотекарства у библиотечко-информационом систему у Србији. Методолошки, рад је производ аналитичко-синтетичке методе, посматрања са учествовањем, а вршена су и проста поређења. Коначно, дошло се до закључка да је ово библиотекарство врло развијено у појединим сегментима али да у општем смислу представља одраз односа друштва према библиотечко-информационој делатности. Другим речима, има довољно простора за унапређење затеченог стања.
\end{abstract}

Кључне речи: ваздухопловне установе, виртуелне библиотеке, високошколске библиотеке, специјалне библиотеке

\section{Организације у којој постоје библиотека или збирка литературе и извора из области ваздухопловства}

Организационо окружење једне библиотеке која садржи литературу и друге изворе из области ваздухопловства може да варира од сасвим мале до велике и сложене организације. Те организације се могу налазити и на више различитих места у географском смислу, у више градова, али се најчешће налазе на једном месту, у једном граду. 
У домаћем окружењу постоји неколико значајних установа које садрже литературу и изворе из области ваздухопловства. Њихови називи налазе се у азбучном поретку: Аеродром Никола Тесла, Аеродром Константин Велики, Air Serbia, Контрола летења Србије и Црне Горе, SMATSA d.o.o., Ваздухопловна академија, Београд, Ваздухопловни савез Србије, Ваздухопловномедицински институт, Војна академија, Директорат цивилног ваздухопловства Републике Србије, JAT Tehnika d.o.o., Машински факултет Универзитета у Београду, Музеј ваздухопловства, Београд, Саобраћајни факултет Универзитета у Београду.

Библиотеке установа ваздухопловства сврставају се у домен специјалног и високошколског библиотекарства, па се и значај ове теме огледа управо у дефинисању домаћег специјалног и високошколског библиотекарства у области ваздухопловства. Библиотека Ваздухопловне академије је школска библиотека и представља, у овом контексту, изузетак.

Класификација коју је дао УНЕCKO (UNESCO) дели све библиотеке на националне, јавне, школске, високошколске и специјалне, а према Закону о библиотечко-информационој делатности, постоји национална, јавна, високошколска, универзитетска библиотека, библиотека научноистраживачког института и установе, специјална, као и информациони центри при другим установама, организацијама или удружењима) (члан 13). Специјалне библиотеке, према Кнежевићу, могу да оснују следеће установе: професионална удружења, трговачка друштва, разне асоцијације; банке, осигуравајућа друштва, рекламне агенције, издавачке, новинске и сличне агенције; богословске школе, цркве и религијске организације; архитектонске, грађевинске и пројектне фирме; историјска, генеолошка и друга слична друштва; индустријска и акционарска друштва која се баве производњом различитих добара и материјала, као и пружањем услуга; научна друштва; медицинске установе (болнице, факултети, друштва); војне установе; музеји; музичке установе (организације, друштва); органи управе (државна, покрајинска, градска); затвори; правни факултети, адвокатске фирме (34-35).

Према Централном регистру библиотека Србије, регистровану библиотеку има седам установа са листе. Неке од њих су затвореног типа, друге су отворене за јавност. Њихови корисници припадају ређе грађанству, а чешће скупини запослених у датој установи односно студентској популацији. Реч је следећим библиотекама: 
- Библиотека Агенције за контролу летења (Контрола летења Србије и Црне Горе, SMATSA доо)

- Библиотека Ваздухопловне академије, Београд

- Библиотека Директората цивилног ваздухопловства Републике Србије

- Библиотека Машинског факултета Универзитета у Београду

- Библиотека Музеја ваздухопловства, Београд

- Библиотека Саобраћајног факултета Универзитета у Београду

- Центар за библиотекарство, војнонаучну документацију и информацију Војне академије

Библиотеке чије услуге може и грађанство користити, наручену библиотечку грађу дају на коришћење искључиво у својим читаоницама односно радном простору или се питање коришћења грађе решава другим, уобичајеним видовима пружања информационих услуга.

Остале установе ваздухопловства немају регистроване библиотеке (Air Serbia, Аеродром Константин Велики, Аеродром Никола Тесла, Ваздухопловни савез Србије, JAT Tehnika doo, Ваздухопловномедицински институт). Библиотечко-информациона грађа постоји; публикације и извори се набављају, али су њихово функционисање и циркулација грађе и извора решени на неки други начин. Наиме, монографске и серијске публикације, као и друге изворе поседују и користе све набројане установе ваздухопловства.

\begin{tabular}{|c|c|}
\hline Назив установе & Тип библиотеке \\
\hline Аеродром Никола Тесла & Нема регистровану библиотеку \\
\hline Аеродром Константин Велики & Нема регистровану библиотеку \\
\hline Air Serbia & Нема регистровану библиотеку \\
\hline $\begin{array}{l}\text { Агенција за контролу летења Србије и Црне } \\
\text { Горе, SMATSA доо Београд }\end{array}$ & Специјална библиотека \\
\hline Ваздухопловна академија, Београд & Школска библиотека \\
\hline Ваздухопловни савез Србије & Нема регистровану библиотеку \\
\hline Ваздухопловномедицински институт & Нема регистровану библиотеку \\
\hline Војна академија & Високошколска библиотека \\
\hline $\begin{array}{l}\text { Директорат цивилног ваздухопловства } \\
\text { Републике Србије }\end{array}$ & Специјална библиотека \\
\hline JAT Tehnika d.o.o. & Нема регистровану библиотеку \\
\hline Машински факултет Универзитета у Београду & Високошколска библиотека \\
\hline Мүзеј ваздухопловства, Београд & Специјална библиотека \\
\hline $\begin{array}{l}\text { Саобраћајни факултет } \text { Универзитета } \\
\text { Београду }\end{array}$ & Високошколска библиотека \\
\hline
\end{tabular}


Тип библиотеке у установама у којима не постоји организациона јединица која би се бавила публикацијама, документацијом и изворима или у смислу овог рада, немају регистроване библиотеке, свакако је специјална библиотека осим у случају ваздухопловномедицинског института. По типу, њихова библиотека би могла да се сврста у библиотеке научноистраживачког института и установе.

\section{Библиотечко-информациона грађа и извори у домену ваздухопловства}

У ваздухопловству, библиотечко-информациони грађу и изворе представљају у принципу исте врсте публикација као и у другим библиотекама. То су књижна и некњижна грађа, као и електронски извори. Конкретно, реч је о књигама, рукописима, брошурама, серијским публикацијама, картографкој грађи, каталозима, календарима, фотографијама, албумима, разгледницама, цртежима, плановима, плакатима и и другој ликовној и графичкој грађи, звучним и видео записима, електронским публикацијама дистрибуираним на физичким носачима, те електронским публикацијама дистрибуираним на интернету (Закон о библиотечко-информационој делатности члан 6). У ваздухопловству важну улогу имају и интегративни извори: Зборник ваздухопловних информација (Aeronautical Information Publication - AIP) који је до недавно имао и класичан облик, а сада излази само као електронски извор.

Али, и у оквиру врсте грађе и извора постоји разноврсност. Иако грађу и изворе чине публикације из области ваздухопловства, као примењене дисциплине, наравно да су присутне и оне из граничних, али и сасвим различитих дисциплина од самог ваздухопловства. Установе ваздухопловства поседују публикације из опште групе (рецимо: библиотекарство, менаџмент), те из хуманистичких и друштвених наука, природних и примењених - нарочито из ваздухопловне технике, али и из архитектуре, уметности, спорта, језика, географије и историје. А осим монографских публикација и континуираних извора (серијске публикације и интегративни извори), ту је и нењижна грађа 
(архивска грађа, преписка између осталог, карте, као имноги други видови) укључујући и различите електронске изворе. Према каталогу WorldCat, електронски извори из области ваздухопловства могу бити осим монографских и серијских публикација које имају оба вида (и класичан и електронски), е-журнали односно е-магазини, електронски у настанку, те архивска грађа односно како стоји у запису: архивска грађа за преузимање, што имплицира електронски облик, те други интернет извори: чланци за преузимање и други електронски (дигитални) документи и електронски извори: компакт дискови и дискете. Подаци добијени прегледањем записа који се односе на електронске изворе говоре управо о њиховој разноврсности. У исто време, отвара се и питање односа (резерве) према њима, поводом прецизности, тачније, доследности у коришћењу стручне терминологије приликом обраде и уноса података с обзиром да је стандардизација у домену описа електронских извора, такође, динамично подручје. Следе примери неких електронских извора у ваздухопловству.

- EASA European Air Safety Agency - to maintain and improve aviation safety in Europe; у опису стоји да је реч о архивској грађи за преузимање односно мрежном извору; без података о години; OCLC number: 731925955

- ICAO journal; у запису стоји да је реч о серијској публикацији односно о е-журналу/е-магазину односно мрежном извору, а на месту временске одреднице стоји 1981. година; OCLC number: 643996755

- La procedure d'evaluation d'EASA : remarques et réflexions/ Comments on the Evaluation EASA Procedure : proceeding, seminar, workshop without peer review; према запису, реч је о компјутерском фајлу (датотеци) односно електронском документу, без временске одреднице; OCLC number: 695129043

- Regulation on Sub-orbital Space Tourism in Europe : a Role for EU/ EASA?; чланак из серијске публикације, за преузимање, дакле, мрежни извор, из 2010. године; OCLC number: 703562816

- A decade of international co-operation..., за који постоји и штампана верзија, али без података о месту излажења, из- 
давачу и години издања; подаци о е-верзији говоре да је реч о компјутерском фајлу односно мрежном извору који је изашао у Бриселу, у издању Одељења Eurocontrol-a за односе са јавношћу; из 1970. године; OCLC number: 697068795

\section{Степен развоја ваздухопловних библиотека у Србији}

Истраживање је пошло од претпоставке да се у ваздухопловним установама поред њихове основне, одвија и библиотечко-информациона делатност, а извршено је са циљем да се утврди степен развоја у овом домену библиотечко-информационе делатности и ваздухопловства, као и проналажење начина за унапређење. Предмет анализе били су организационо окружење, библиотечко-информациона грађа и извори и место ваздухопловног библиотекарства у библиотечко-информационом систему у Србији. Подаци добијени у истраживању највише се везују за годину која претходи интервјуу.

Ради тога, обављен је интервју односно преписка у појединим случајевима, са запосленима који раде у библиотекама установа ваздухопловства или су компетентни односно овлашћени да пруже тражене информације. Спроведени поступак је дао следеће резултате.

У свим установама ваздухопловства обавља се библиотечкоинформациона делатност, у потпуности или делимично. Реч је и о библиотекама као саставним јединицама дате установе, дакле, регистрованим библиотекама, али и о збиркама публикација односно извора и докумената. Те библиотеке (збирке) налазе се у саставу неке друге установе: државног органа, привредног предузећа, образовне установе или удружења. Већ је речено да су то специјалне и високошколске, као и једна школска библиотека.

Уколико постоје књиге инвентара, не постоје у свим установама о којима је реч. Ни за све врсте библиотечко-информационе грађе не воде се књиге инвентара. Библиотеке су смештене у посебним просторијама, као и публикације и документација, уколико је реч о регистрованим библиотекама, а у осталим случајевима публикације и извори расути су у материјалном и виртуелном простору, па ни питање евиденције библиотечко-информационе грађе и извора није сасвим решено. 
Високошколске библиотеке имају и читаонице за своје кориснике. Услови за обављање библиотечко-информационе делатности варирају од врло добрих до незадовољавајућих. Неки од запослених на пословима библиотекара односно компетентних за пружање информација о публикацијама и изворима сматрају да би им чешће или ређе, добро дошле сугестије у циљу унапређења библиотечко-информационе делатности и то од стране различитих саговорника: запослених унутар установе, спољних сарадника, библиотекарског друштва, удружења специјалних библиотека или матичне библиотеке.

Сви саговорници су имали рачунар на радном месту, а конфигурација је варирала од случаја до случаја. У једној библиотеци постоји програм посебно развијен за дату библиотеку. Остале библиотеке користе већ постојеће програме; реч је најчешће о Cobiss-y. У случају високошколских библиотека постоје и услуге електронске читаонице. Приступ светској мрежи имају све библиотеке али има случајева да је мрежа нестабилна што често онемогућава рад у том домену. Неке од установа имају и локалну рачунарску мрежу. Све библиотеке су у мањој или већој мери опремљене различитом техничком опремом (скенер, штампач, видео-бим, пројектор).

Библиотеке и остале установе ваздухопловства своју грађу и изворе набављају путем куповине или сопственог издаваштва, у појединим случајевима. И други видови набавке функционишу: међубиблиотечка позајмица, као и конзорцијум за обједињену набавку. Библиотеке располажу тачним бројем својих публикација и извора, док у осталим установама не постоји тачна или континуирана евиденција о грађи. Осим на матерњем, публикације су на матерњем и на енглеском, и у мањој мери на другим језицима.

\section{Разумевање матичне установе за питања ваздухопловног библиотекарства}

Место ваздухопловног библиотекарства у библиотечко-информационом систему у Србији представља заправо низ тема. Пошто је већином реч о специјалним и високошколским библиотекама, њих прате проблеми са којима се сусрећу библиотеке тог типа. Специфич- 
но је то што су, као релативно младе дисциплине, ваздухопловство и информационе технологије бележили убрзан развој у другој половини прошлог века, а савремено ваздухопловство имплицира употребу информационо-комуникационих технологија на високом нивоу, од стране установа ваздухопловства као стране која пружа услуге и као од стране која их користи. Из тога следи да је библиотекарство у домену ваздухопловства пратило динамику развоја поменуте две дисциплине. Ипак, не постоји усаглашеност у том смислу.

Испитивање задовољства корисника публикација и извора из ваздухопловства, у истраживању за овај рад, није предвиђено због временских оквира, па не постоје подаци у том смислу, који би били од значаја за стицање целокупне слике о библиотечко-информационим и сличним услугама које пружају библиотеке или друге јединице установа ваздухопловства.

Степен задовољства библиотекара у установама ваздухопловства различит и варира. У зависности је од самог запосленог, радног окружења и временске одреднице. Највећи утицај има управна структура односно прва линија надређених библиотекару и најмоћнија особа у окружењу без обзира на формалну позицију у организацији. Треба узети у обзир и чињеницу да истраживање није обављано са анонимним испитаницима, па се може очекивати да одговори које пружају запослени не даје стварну слику.

Упитник је дао одговор на питање да ли је на место библиотекара постављен запослени едукован за матичну (главну, претежну делатност) односно едуковани библиотекар. Ни у једној библиотеци није запослена особа која има образовне квалификације из обе дисциплине: библиотекарство и информационе науке, те ваздухопловство, а чешће је случај да су ангажовани стручњаци из неке треће дисциплине. Ово је устаљена пракса колико у домаћим библиотекама, толико и у инстранству.

\section{Спој теорије и праксе}

Методолошки, рад је производ аналитичко-синтетичке методе, посматрања са учествовањем у дужем временском периоду, а врше- 
на су и проста поређења, са местом истраживања у библиотечкој средини у различитим установама ваздухопловства. По образовању контролор летења и библиотекар-информатичар, ауторка је у пракси из области библиотекарства и информационих наука провела приближно петнаест година, с тим да је у специјалној библиотеци у установи ваздухопловства била распоређена три године. У самом ваздухопловству, у некадашњој Савезној управи за контролу летења, била је запослена преко петнаест година, а једанаест година поседовала дозволу (лиценцу) контролора летења односно помоћника. Стога, рад представља спој теорије и праксе из обе дисциплине.

\section{Коначна реч}

Реномиране ваздухопловне установе, у свету и код нас, требало би да у складу са значејем у овиру своје заједнице, имају и своје библиотеке односно јединице за информациону делатност, центре за документацију или издавачку делатност, те медијатеке - како год да се те јединице данас називају. У складу са развојем матичне делатности, стварају се и услови за развој библиотечко-информационе делатности у тој дисциплини. Ипак, у пракси је потврђено да не постоји раширена свест о значају једне уређене колекције записа и извора. Библиотеке постоје тамо где закон обавезује на њихово постојање, али не и на свим местима на којима постоји потреба за информационим пунктом без обзира на назив те јединице, као и на чињеницу да се у датој установи обављају поједини видови библиотечко-информационе делатности. Ово је потврђено у општем смислу, па и у случају установа ваздухопловства, посебно данас, у време електронских извора.

Ипак, непобитне су следећечињенице. Неопходност коришћења савремених информационо-комуникационих технологија и природа ваздухопловне информације чине предуслове да се ваздухопловним библиотекама међу првима додели атрибут виртуелног. Прича о виртуелном ваздухопловном библиотекарству тече од осамдесетих година двадесетог века. Међутим, само на основу записа из електронског каталога не може се са сигурношћу донети суд о коришћењу 
првих електронских извора. Истраживање за овај рад није донело као резултат прецизне податке о години у којој су први пут у датој библиотеци почели да набављају, евидентирају, а самим тим и користе било какав електронски извор, дакле, грађу посредством рачунара. Детаљнији приказ захтева посебна истраживања што отвара нека нова поглавља.

Ваздухопловно библиотекарство врло је развијено у погледу врсте библиотечко-информационе грађе, а нарочито у домену електронских извора. Међутим, у општем смислу представља одраз односа друштва према библиотечко-информационој делатности. Другим речима, има довољно простора за унапређење затеченог стања, у различитим правцима.

\section{Литература}

Закон о библиотечко-информационој делатности. Службени гласник Републике Србије. 2011. Web. 11 feb. 2017.

Knežević, Branko B.. Specijalno bibliotekarstvo. Beograd: Требник, 2002. Print.

\section{Ljiljana Macura}

National Library of Serbia

\section{LIBRARIES OF AERONAUTICAL INSTITUTIONS IN SERBIA}

\section{Summary}

The necessity of using modern information and communication technologies and the nature of aeronautical information imply that aeronautical institutions' libraries were among the first libraries to get the virtual attribute. Libraries of aviation institutions are classified into the domain of special and academic librarianship, so the importance of this topic is reflected in defining the domestic special and academic librarianship in the field of aviation. The study was based on the assumption that the aeronautical insti- 
tutions in addition to their basic activity (task) perform library (and information) function as well. The investigation carried out in order to determine the level of development in the field of library and information work in aeronautical institutions and to find out apropriate ways how to improve. The subject of the analysis were organizational environment, library and information materials and resources and position of aeronautical institutions' libraries in library information system in Serbia. In methodological terms, this work is the product of analitic and synthetic methods, observing and participation and product of simple comparisons. Finally, it was concluded that this librarianship is highly developed in certain segments but in general it is a reflection of society towards library and information work. In other words, there is plenty of room for improvement of the status quo.

Key words: aeronautical institutions, virtual libraries, academic libraries, special libraries 